\title{
The earliest leperditicope arthropod: a new genus from the Ordovician of Spitsbergen
}

\author{
MARK WILLIAMS \& DAVID J. SIVETER \\ Department of Geology, University of Leicester, Leicester LE1 7RH, UK (e-mail: mri@le.ac.uk, djs@le.ac.uk)
}

\begin{abstract}
A new leperditicope from the carbonate-dominated sequence of the Nordporten Member of the Kirtonryggen Formation, Spitsbergen, is the oldest confirmed representative of this group of bivalved arthropods. It occurs at a stratigraphical level low in the Floian Stage of the Early Ordovician, and below rocks bearing graptolites of the Pendeograptus fructicosus Biozone. Its occurrence emphasizes an 'out of Laurentia' palaeogeographical origin for leperditicopes, though there are no obvious antecedents in the earlier, Cambrian record of that palaeocontinent. J. Micropalaeontol. 27(2): 97-101, November 2008 .
\end{abstract}

KEYWORDS: Ordovician, leperditicope arthropod, origins, Spitsbergen

\section{INTRODUCTION}

Leperditicopida are large bivalved arthropods typically $5-50 \mathrm{~mm}$ in length. Conventionally treated as ostracods (e.g. Whatley et al., 1993), their biological affinities are unclear, compounded by a lack of evidence from soft tissue preservation and the absence of post-Devonian representatives of the group (Vannier et al., 2001). Leperditicopes first become common in the Middle Ordovician of North America and Greenland (e.g. Poulsen, 1937; Harris, 1957, 1960; Berdan, 1976, 1984). From their earliest occurrences, in palaeocontinental Laurentia, leperditicopids spread to become global in the Silurian. Berdan (1984) summarized their stratigraphical distribution, taxonomic nomenclature and morphological characteristics. Here, a new and early occurrence of an isochilind leperditicope is reported from the Early Ordovician Nordporten Member of the Kirtonryggen Formation, Spitsbergen.

\section{MATERIAL AND LOCALITY}

The leperditicope material was collected from the Kirtonryggen Formation in north Ny Friesland, Spitsbergen, during fieldwork by Richard Fortey and David Bruton in 1971 (Fortey \& Bruton, 1973; see Fig. 1). Outcrops of the Nordporten Member occur north and south of Buldrebreen, an arm of the Valhallfonna Glacier. The Nordporten Member is exposed along the shore of the northern outcrop and in the upper reaches of the Profilbekken (Fig. 1). In the southern area it forms a flat-topped mountain, Bordtoppen, and is partly exposed along stream sections inland along Olenidsletta. On the coast along Profilstranda, Fortey \& Bruton (1973, p. 2232) calculated that the thickness of the Nordporten Member is $220 \mathrm{~m}$. The carbonate-dominated sequence of the Nordporten Member is fossiliferous throughout and includes trilobites, leperditicopes and nautiloids. Leperditicopes and ostracods are also present in the overlying Valhallfonna Formation (R.A. Fortey unpublished information).

\section{STRATIGRAPHICAL SETTING: THE OLDEST LEPERDITICOPE}

The Order Leperditicopida is divided into two families, the Isochilinidae Scott, 1961, with valves that are essentially equalsized, and the Leperditiidae Jones, 1856, with valves that are asymmetrical (see Berdan, 1984). Confirmed earliest occurrences of both families are in the Ordovician of North America, but records of isochilinds are the oldest (Berdan, 1984). The record of Leperditia harrisi Frederickson, 1946 from the Late Cambrian of Oklahoma is based on a single specimen figured only in outline (Frederickson, 1946, figs 1-3). As noted by Vannier et al. (2001), the shape of $L$. harrisi strongly suggests that it is not a leperditicope. The oldest yet described isochilind is Tirisochilina juabaria Berdan, 1976 from the Juab Limestone of Utah, and

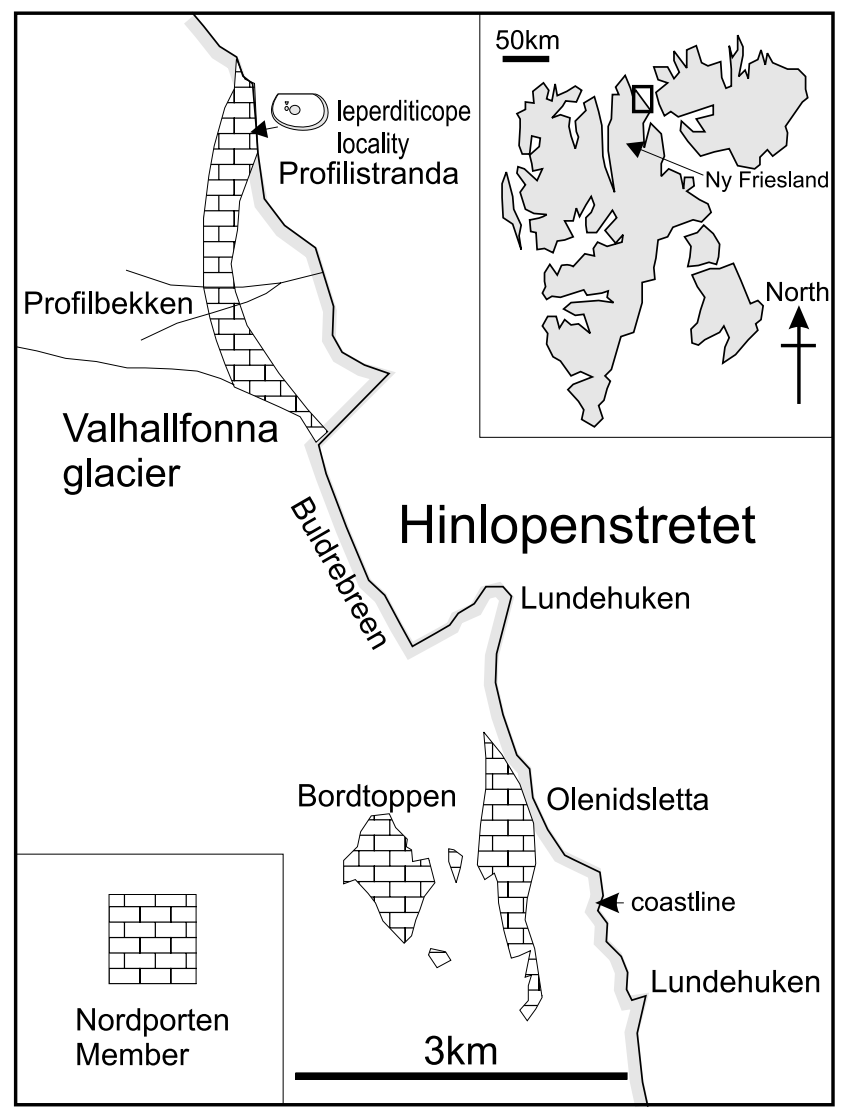

Fig. 1. Geographical location of the leperditicope-bearing sequence in Spitsbergen (map after Fortey \& Bruton, 1973, fig. 1). The leperditicopes are from the northern outcrop of the Nordporten Member. 
was referred at the time it was described to an early 'Chazyan' horizon. A number of leperditicopes are also recorded from the immediately overlying Kanosh Shale (Berdan, 1976, text-fig. 2). The Juab Limestone is assignable to the Psephosthenaspis trilobite Biozone (see Fortey \& Droser, 1996), indicating an early 'Whiterockian' age, equivalent to the 'Third Stage' of Cooper \& Sadler (2004). Leperditicopes are known from still earlier deposits in North America, particularly from the uppermost part of the West Spring Creek Formation in Oklahoma (Harris, 1957). This formation and its equivalents yield Didymograptus protobifidus (e.g. Decker, 1945) and probably have a latest Early Ordovician age (Overstreet et al., 2003; see Cooper \& Sadler, 2004). Leperditicopes became very widespread in North America during the Middle and Late Ordovician (e.g. Harris, 1957; Swain, 1957; Berdan, 1984).

The new leperditicope from Spitsbergen occurs in the carbonate-dominated sequence of the Nordporten Member of the Kirtonryggen Formation, deposited in a shallow-marine shelf setting (Fortey \& Bruton, 1973). The Nordporten Member immediately precedes the black graptolitic limestone and shale of the Olenidsletta Member of the Valhallfonna Formation, which bears graptolites assignable to the Pendeograptus fructicosus graptolite Biozone (see Fortey \& Bruton, 1973; Cooper \& Fortey, 1982; Maletz \& Bruton, 2005). This indicates a level low in the Floian Stage of the Early Ordovician ('Second Stage' sensu Cooper \& Sadler, 2004) and places the isochilind material from Spitsbergen as the oldest (c.475 Ma) confirmed representative of the family and order. The closest taxon to the Spitsbergen material appears to be the North American Kenodontochilina, which occurs somewhat later in the Lexington Limestone, Ashlock and Bull Fork formations, Late Ordovician, Kentucky (Berdan, 1984).

The oldest supposed ostracods (Palaeocopida) are those from the Tremadocian of palaeocontinental Baltica (Tinn \& Meidla, 2004), Gondwana (Salas et al., 2007) and the Gondwanan margins (Williams, M. Ghobadi Pour and L. E. Popov, unpublished information). There are no Early Ordovician leperditicopes from Gondwana, and that group appears to be confined to Laurentia for the Ordovician (Fig. 2): the unusual record of leperditicopes from the supposed Ordovician of Japan (Adachi \& Igo, 1980) has been shown to be Devonian in age (Wang \& Peng, 2004). The notion of an independent origin for leperditicopes and ostracods (e.g. Vannier et al., 2001) is supported by their apparent separate palaeocontinental origins.

\section{ORIGINS OF THE LEPERDITICOPES}

Vannier et al. (2001, p. 75) regarded records of leperditicopes from the Late Cambrian of North America to be doubtful and, indeed, Siveter \& Williams (1997, p. 17) had earlier treated these in their discussion of the arthropod group Bradoriida. Copeland (1962) suggested an Early Ordovician isochilind antecedent for the Leperditiidae that is consistent with the early occurrence of leperditicopes in Spitsbergen. However, there are currently no obvious antecedents for leperditicopes in the Tremadocian or Cambrian. Amongst the various bivalved arthropods referred to the Bradoriida (see Williams et al., 2007), some forms such as the Cambrian Anabarochilina have large bivalved carapaces, with equal-sized valves and a concentration of lobes anteriorly. Similar to some leperditicopes, they also possess anastomosing

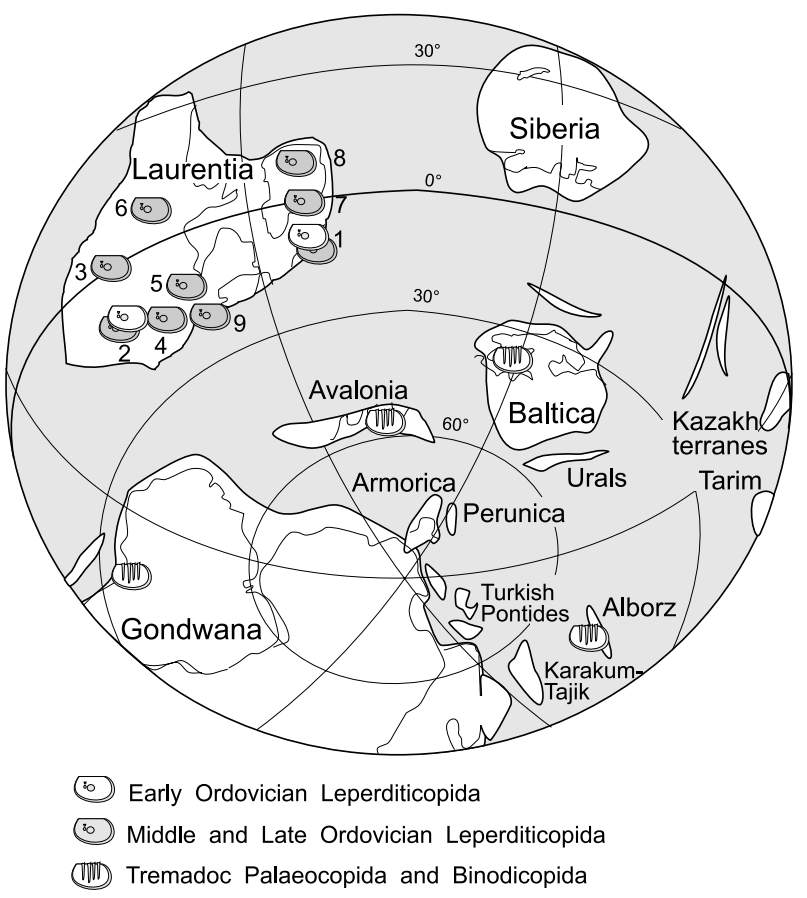

Fig. 2. Palaeogeographical setting of the earliest leperditicopes (reconstruction of a Darriwilian palaeogeography, courtesy of Dr Leonid Popov). Also shown are the oldest (Tremadocian) records of palaeocopid and binodicopid ostracods and later Ordovician occurrences of Leperditicopida (list not exhaustive for the whole of North America). 1, Spitsbergen (this paper, the record of Middle Ordovician leperditicopes is based on unpublished data of R. A. Fortey); 2, West Spring Creek Formation and Simpson Group of Oklahoma (Harris, 1957); 3, Juab Limestone and Kanosh Shale of Utah (Berdan, 1976, 1984); 4, Kentucky (Berdan, 1984); 5, Ontario (Copeland, 1965); 6, Northwest Canada (e.g. Copeland, 1978); 7, East Greenland (Poulsen, 1937); 8, North Greenland (Teichert, 1937); 9, northeastern USA (Pennsylvania, New York \& Vermont; Swain, 1957).

ridges extending out from the nodes that probably represent the trace of an integumental circulatory system (e.g. see Vannier et al., 1997; Hou et al., 2002). However, these features are plesiomorphic and are shared by a number of different arthropod groups (e.g. Vannier et al., 1997). Most importantly, no known bradoriid has a calcium carbonate carapace, or possesses the complex muscle scars that characterize the leperditicopes (Berdan, 1984). The origin of the leperditicopes remains enigmatic and may be resolved only by the discovery of specimens with soft anatomy preservation.

\section{SYSTEMATIC PALAEONTOLOGY}

The terminology of the leperditicope carapace is that used by Berdan (1984) and Vannier et al. (2001; see Fig. 3). The specimens are housed in the collections of the Department of Palaeontology, Natural History Museum, London.

Phylum Arthropoda Siebold \& Stannius, 1845 Class Uncertain

Order Leperditicopida Scott, 1961

Family Isochilinidae Swartz, 1949

Genus Trinesos gen. nov. 


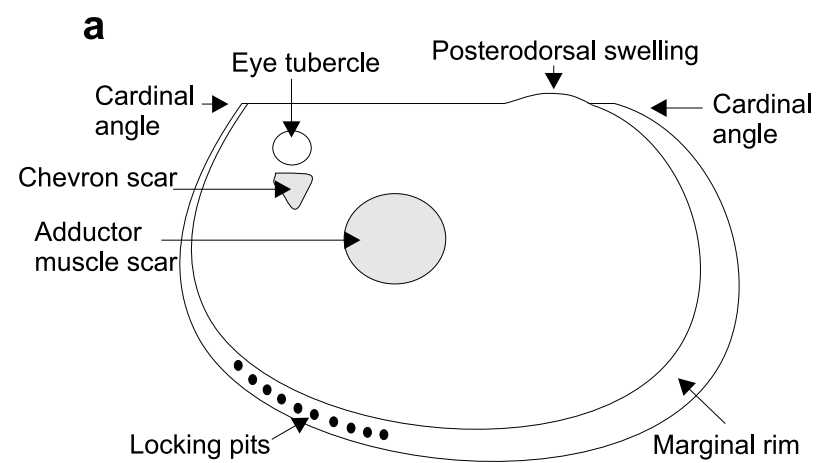

b

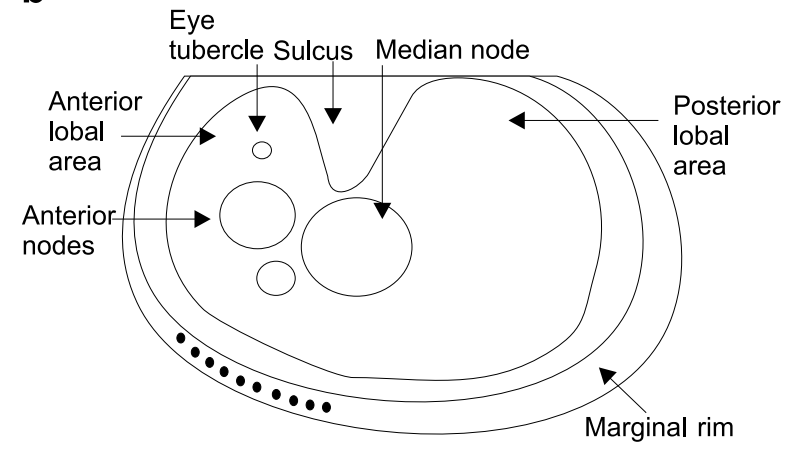

Fig. 3. Terminology applied to the isochilind carapace: (a) general isochilind morphology (after Berdan, 1984); (b) morphology as applied to Trinesos akroria.

Type species. Trinesos akroria gen. et sp. nov.

Derivation of the name. Trinesos, from Greek, trion 'three' and nesos 'island'. Fancied resemblance of the three nodes to islands. For Professor Richard Fortey, who collected this material and whose surname in old English means 'land standing out from a surrounding marsh or fen'. Gender feminine.

Diagnosis. Isochilind with large circular submedian node (greater than $0.5 \mathrm{~mm}$ diameter in specimens longer than $3.5 \mathrm{~mm}$ ), separated from two smaller anterior nodes by a distinct sulcus. Anterior nodes comprise of a small circular node anteroventrally and a larger circular node situated both dorsal of this node and slightly dorsally of the submedian node. Locking pits are developed from midventral to anteroventral region in the right valve. Marginal rim entire.

Remarks. The new genus is clearly referable to the Isochilinidae by its possession of a lateral rim and planar commissure (Berdan, 1984, p. 4). As noted by Berdan (1984, p. 4), isochilinds often bear 'extreme' lobation, though such 'extremes' also occur in some Leperditiidae Jones, 1856, particularly Sibiritia Abushik (e.g. see Abushik et al., 1989, pl. 3, fig. 22a).

Trinesos appears to belong to a group of multilobate Ordovician isochilinds that include Kenodontochilina Berdan, 1984 and Saffordellina (Ulrich \& Bassler, 1923). Possession of three or more nodes clearly distinguishes this group from other isochilinds, including the type genus Isochilina Jones, 1858 and the closely related Teichochilina Swartz, 1949. The lobation of Trinesos most closely resembles Kenodontochilina from the
Ordovician of eastern North America (e.g. 'Ctenobolbina clavigera'; for which, see Copeland, 1958; Berdan, 1984). Kenodontochilina has valves with a distinct sulcus separating a median 'boss' from a well-developed anterodorsal eye tubercle. The position of both of these nodes in Kenodontochilina is more dorsal than in Trinesos and, in addition, Kenodontochilina bears up to two additional dorsal nodes posterior of the eye tubercle. The North American Ordovician Saffordellina also possesses a large submedian node, but has a number of additional lobes both anterior, dorsal and posterior of this, and a well-developed ridge running parallel to the valve margin from the anterodorsal to mid-posterior part of the valve (for illustrations of these taxa, see Berdan, 1984).

Many leperditicopes bear an adductor muscle scar and in Kenodontochilina this is situated on the large submedian 'boss'. No muscle scars are preserved in the material of Trinesos, though this may be a factor of preservation, as in most cases the equivalent muscle scar-bearing node is abraded (Figs 4.1, 4.3, 4.7-4.9). However, a slightly raised ellipsoidal-shaped area, dorsal of the three nodes on the external surface and at the base of the sulcus, might reflect the point of attachment of the adductor muscle internally (Figs 4.1, 4.3, 4.5, 4.8).

Trinesos akroria sp. nov.

(Figs 4.1-4.9)

Derivation of the name. Greek akroria, meaning 'daybreak', alluding to the early occurrence of this leperditicope.

Diagnosis. As for genus, which is monotypic.

Holotype. A right valve (Figs 4.1, 4.4), NHM OS 16535 (R.A. Fortey, field collection number F5494), 4.4 mm long.

Material. Eight disarticulated valves, ranging in length from $1.6 \mathrm{~mm}$ to $4.4 \mathrm{~mm}$, and probably representing three or more growth stages (NHM OS 16535-16540).

Description. Isochilind with postplete outline and valves up to $4.4 \mathrm{~mm}$ long. Posterocardinal and anterocardinal angles pronounced. Well-developed sulcus in the adductorial position in the dorsal-most third of the valve. This sulcus subdivides the valve into broad and inflated posterior and anterior lobal areas. Three prominent lateral nodes are developed ventral of the sulcus: large (greater than $0.5 \mathrm{~mm}$ diameter in specimens longer than $3.5 \mathrm{~mm}$ long), circular submedian node separated from two anterior nodes by a distinct sulcus. Anterior nodes comprise a small circular node anteroventrally and a larger circular node situated dorsal of this node and also slightly dorsal of the submedian node. The three nodes and the sulcus are well developed in early ontogeny (Fig. 4.2). A small raised area dorsal of the anterodorsal-most node appears to represent the trace of an 'eye tubercle' (Fig. 4.1). Posterodorsal swelling absent. A slightly raised area which is ellipsoidal in shape forms a 'muscle area' dorsal of the three nodes, but no chevron, subocular or adductor scar is preserved (cf. Fig. 3). At least nineteen tiny locking pits are developed from midventral to anteroventral along the marginal rim in the right valve (Figs 4.1, 4.4). Marginal rim entire, deepest anteriorly, widest posterodorsally and weakest ventrally. Small juveniles have smooth 


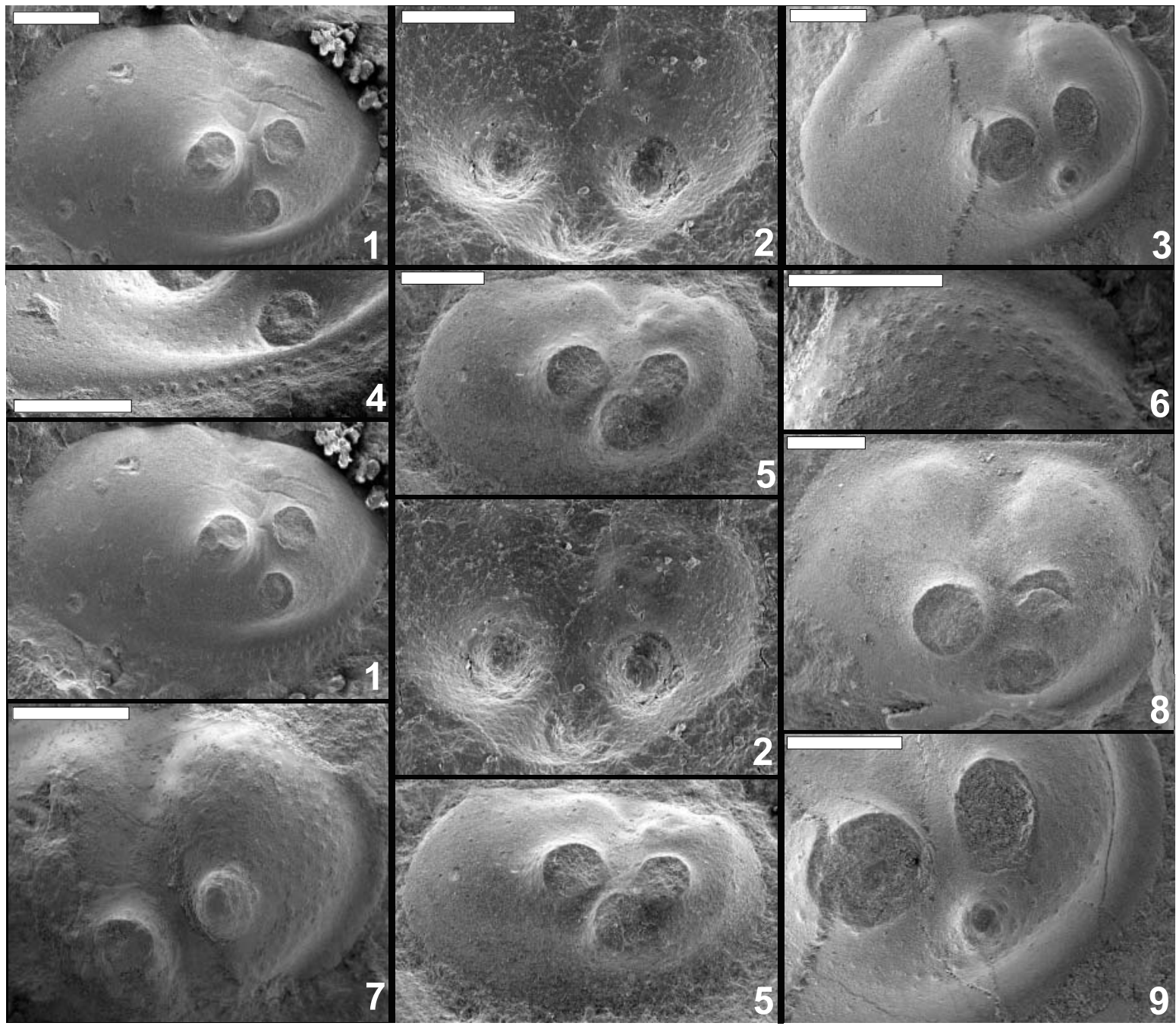

Fig. 4. Trinesos akroria from the Nordporten Member, Kirtonryggen Formation, Spitsbergen. (1, 4) Holotype, RV lateral view, stereo-pair and close up of anteroventral margin respectively, NHM OS 16535 (field collection number F5494). (2) Latex cast of juvenile RV, lateral view, stereo-pair, NHM OS 16536. (3,9) RV lateral view and close up of anteroventral part of valve, NHM OS 16537 (field collection number F4528). (5) RV lateral view, stereo-pair, NHM OS 16538. (6,7) Close up of pustulose ornament and RV lateral view respectively, NHM OS 16539 (field collection number F5466). (8) RV lateral view, NHM OS 16540 (field collection number F5504). Scale bars are: 1, 6, 7=1 mm; 2, 5, 8=0.5 mm; 3, 9=0.7 mm; 4=1.5 mm.

valve surfaces; larger juveniles and adults have discrete, spaced pustules.

Remarks. T. akroria differs from all other species of isochilind in the development and position of its three well-developed lateral nodes. Although the lobation of T. akroria is unique, the species bears some similarity to Kenodontochilina? clavigera (Jones, 1891) from the Pamelia Beds of the Ottawa Formation (see Copeland, 1958; Berdan, 1984). K.? clavigera has a welldeveloped sulcus and the anterior and posterior parts of the valve are divided into broad lobal surfaces (labelled 'L1' and 'L3' by Copeland, 1958). However, K.? clavigera has an additional sulcus (which is also evident in other species of Kenodontochilina, see Berdan, 1984, pl. 10) and the morphology of the nodes on the valve surface is quite different from that of T. akroria.

Elsewhere in the Arctic region, Middle and Late Ordovician leperditicopids have also been reported from the Narwhal
Sound Formation (basal Whiterockian), Ella Island, and Wright Bay Formation (Ashgillian), Cape Calhoun, Washington Land, East and North Greenland respectively (Poulsen, 1937; Teichert, 1937), but these are Leperditiidae (Berdan, 1984; for relevant stratigraphy of East Greenland, see Smith et al., 2004).

\section{ACKNOWLEDGEMENTS}

The authors thank Jean Vannier (Lyon) and Maria José Salas (Córdoba, Argentina) for their constructive reviews of this paper. Mark Williams thanks Leicester University for study leave. Giles Miller (Natural History Museum) sourced a number of key references and Leonid Popov (National Museum of Wales) provided the palaeogeographical reconstruction of Figure 2. Richard Fortey is also thanked for providing the materials for this study, and Adrian Rushton (Natural History Museum) is thanked for discussion. 


\section{Manuscript received 19 July 2007 \\ Manuscript accepted 12 December 2007}

\section{REFERENCES}

Abushik, A.F., et al. 1989. Palaeozoic ostracodes. In: Sokolov, B.S. (Eds), Prakticheskoe rukovodstvo po mikrofaune SSSR[Practical Handbook on Microfossils of the USSR], 4: 355pp. [In Russian.].

Adachi, Adachi \& Igo, Hisayoshi 1980. A new Ordovician leperditiid ostracode from Japan. Japan Academy, Proceedings, series B, Physical and Biological Sciences, 56: 504-507.

Berdan, J.M. 1976. Middle Ordovician leperditicopid ostracodes from the Ibex Area, Millard County, western Utah. Brigham Young University Geology Studies, 23: 37-63.

Berdan, J.M. 1984. Leperditicopid ostracodes from Ordovician rocks of Kentucky and nearby states and characteristic features of the Order Leperditicopida. Geological Survey Professional Paper, 1066-J: 40pp.

Cooper, R.A. \& Fortey, R.A. 1982. The Ordovician graptolites of Spitsbergen. Bulletin of the British Museum, Natural History, London (Geology), 36: 157-302.

Cooper, R.A. \& Sadler, P.M. 2004. The Ordovician Period. In: Gradstein, F.M., Ogg, J.G. \& Smith, A.G. (Eds), A Geological Time Scale 2004. Cambridge University Press, Cambridge, 165-187.

Copeland, M.J. 1958. Redescription of Ctenobolbina clavigera (Jones) 1891 from the middle Ordovician of Ottawa, Canada. Journal of Paleontology, 32: 236-238.

Copeland, M.J. 1962. Canadian fossil Ostracoda, Conchostraca, Eurypterida, and Phyllocarida. Some leperditiid ostracodes from northern Canada. Geological Survey of Canada Bulletin, 91: 1-8.

Copeland, M.J. 1965. Ordovician Ostracoda from Lake Timiskaming, Ontario. Geological Survey of Canada Bulletin, 127: 1-52.

Copeland, M.J. 1978. Early Paleozoic ostracode assemblages, Northwestern Canada. Geological Association of Canada Special Paper, 18: 93-111.

Decker, C.E. 1945. Early Ordovician graptolites from Big Canyon, Oklahoma. Journal of Paleontology, 19: 607-611.

Fortey, R.A. \& Bruton, D.A. 1973. Cambrian-Ordovician rocks adjacent to Hinlopenstretet, North Ny Friesland, Spitsbergen. Geological Society of America Bulletin, 84: 2227-2242.

Fortey, R.A. \& Droser, M.L. 1996. Trilobites at the base of the Middle Ordovician, western United States. Journal of Paleontology, 70: 73-99.

Frederickson, E.A. 1946. A Cambrian ostracode from Oklahoma. Journal of Paleontology, 20: 578.

Harris, R.W. 1957. Ostracoda of the Simpson Group. Oklahoma Geological Survey, Bulletin, 75: 333pp.

Harris, R.W. 1960. Ceratoleperditia arbucklensis in Criner Hills of Oklahoma. Oklahoma Geology Notes, 24: 93-95.

Hou Xianguang, Siveter, D.J., Williams, M. \& Feng, Xianghong 2002. A monograph of the Bradoriid arthropods from the Lower Cambrian of SW China. Transactions of the Royal Society of Edinburgh, Earth Sciences, 92: 347-409.

Jones, T.R. 1856. Notes on the Palaeozoic bivalved Entomostraca No. 3, some species of Leperditia. Annals and Magazine of Natural History, series 2, 17: 81-101.

Jones, T.R. 1858. Notes on the Palaeozoic bivalved Entomostraca No. 4 , some North American species. Annals and Magazine of Natural History, series 3, 1: 241-245.
Jones, T.R. 1891. On some Ostracoda from the CambroSilurian, Silurian and Devonian rocks. Contributions to Canadian Micropalaeontology, part 3, no. 5: 59-99.

Maletz, J. \& Bruton, D.L. 2005. The Beothuka terranova (Radiolaria) assemblage and its importance for the understanding of early Ordovician radiolarian evolution. Geological Magazine, 142: 1-11.

Overstreet, R.B., Obuh-Ikuenobe, F.E. \& Gregg, J.M. 2003. Sequence stratigraphy and depositional facies of Lower Ordovician cyclic carbonate rocks, southern Missouri, USA. Journal of Sedimentary Research, 73: 421-433.

Poulsen, C. 1937. On the lower Ordovician faunas of East Greenland. Meddeleslser om Grønland, 119(3): 72pp.

Salas, M.J., Vannier, J. \& Williams, M. 2007. Early Ordovician ostracods from Argentina: their bearing on the origin of the binodicope and palaeocope clades. Journal of Paleontology, 81: 1384-1395.

Scott, H.W. 1961. Order Leperditicopida Scott, n. order. In: Moore, R.C. (Ed.), Treatise on Invertebrate Paleontology, Part Q, Arthropoda 3, 3. Geological Society of America and University of Kansas Press, Boulder, Colorado and Lawrence, Kansas, Q103-Q110.

Siebold, C.T.E. Von \& Stannius, H.F. 1845. Lehrbuch der vergleichenden Anatomie der Wirbeltiere. Veit Publishers, Berlin, xii+482pp.

Siveter, D.J. \& Williams, M. 1997. Cambrian bradoriid and phosphatocopid arthropods of North America. Special Papers in Palaeontology, 57: $1-69$.

Smith, P.M., Rasmussen, J.A., Roberston, S., Higgins, A.K. \& Leslie, A.G. 2004. Lower Palaeozoic stratigraphy of the East Greenland Caledonides. Geological Survey of Denmark and Greenland Bulletin, 6: $5-28$.

Swain, F.M. 1957. Early middle Ordovician Ostracoda of the eastern United States. Part 1. Stratigraphic data and description of Leperditiidae, Aparchitidae and Leperditellidae. Journal of Paleontology, 31: 528-570.

Swartz, F.M. 1949. Muscle marks, hinge and overlap features, and classification of some Leperditiidae. Journal of Paleontology, 23: 306-327.

Teichert, C. 1937. A new Ordovician fauna from Washington Land, North Greenland. Meddeleslser om Grønland, 119(1): 65pp.

Tinn, O. \& Meidla, T. 2004. Phylogenetic relationships of Early Middle Ordovician ostracods of Baltoscandia. Palaeontology, 47: 199-221.

Ulrich, E.O. \& Bassler, R.S. 1923. Paleozoic Ostracoda; their morphology, classification and occurrence. Maryland Geological Survey, Silurian: 279-391.

Vannier, J.M.C., Williams, M. \& Siveter, D.J. 1997. The Cambrian origin of the circulatory system of crustaceans. Lethaia, 30: 169-184.

Vannier, J.M.C., Wang, S.-Q. \& Coen, M. 2001. Leperditicopid arthropods (Ordovician-Late Devonian): functional morphology and ecological range. Journal of Paleontology, 75: 75-95.

Wang, Wang \& Peng, Jinlan 2004. Biostratigraphical significance of the Devonian Sinoleperditiini (Ostracoda). Science in China, series $D$ Earth Sciences, 48: 1666-1672.

Whatley, R.C., Siveter, D.J. \& Boomer, I. 1993. Arthropoda (Crustacea: Ostracoda). In: Benton, M.J. (Ed.), The Fossil Record 2. Chapman \& Hall, London, 343-356.

Williams, M., Siveter, D.J., Popov, L.E. \& Vannier, J.M.C. 2007. Biogeography and affinities of the bradoriid arthropods: cosmopolitan microbenthos of the Cambrian seas. Palaeogeography, Palaeoclimatology, Palaeoecology, 248: 202-232. 